原著

術前超音波検査成績からみた胸部食道癌に対する頸部郭清の適応

鹿児島大学医学部第 1 外科

\begin{tabular}{|c|c|c|c|c|c|}
\hline 福元 & 俊孝 & 吉中 平次 & 森永 & 敏行 & 夏越 \\
\hline 徳田 & 和信 & 島田麻里緒 & 白尾 & 一定 & 草野 \\
\hline & 政道 & 愛甲 & & & \\
\hline
\end{tabular}

胸部食道に対する頸部郭清の適応について，鎖骨上と反回神経沿いリンパ節の術前超音波診断なら びに手術成績の面から検討した。 対象は1986年から93年に cI 以上の切除を行った胸部食道癌136例 ( 3 領域郭清105例， 2 領域郭清31例）とした。 3 領域郭清例に抢いて，術前に鎖骨上リンパ節転移陰性と した 84 例中 7 例 $(8.3 \%)$ に組織学的に転移が認められた. False negative 7 例中 5 例は反回神経沿い に術前超音波診断および術中に転移を認めた。したがって，術前超音波診断による鎖骨上リンパ節の 転移の有無のみで頸部郭清を省略するのは危険であるが，反回神経沿いリンパ節の術前・術中診断を 加味すると $97.6 \%(82 / 84$ 例) の症例で頸部郭清の適応を術前診断にて判断可能であったままた術前に 鎖骨上・反回神経沿いに転移陰性とした $\mathrm{mp}$ 以上の症例に扝ける 5 生率は頸部郭清の有無に関係なく $37 \%$ あった，術前診断による鎖骨上または反回神経沿い転移陽性症例が顓部郭清の適応である.

Key words : 3-field lymph node dissection, ultrasonography, endoscopic ultrasonography, preoperative diagnosis

\section{緒言}

教室では, 胸部食道癌の成績向上のために1983年か らある一定条件のもとに積極的に 3 領域郭清を施行し てきた。その結果，リンパ節転移の実態や再発状況,

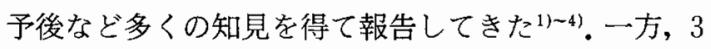
領域郭清は合併症の頻度も高く, 手術侵襲の大きいの も事実である。したがって，不必要な侵襲を避けるた めにも画一的な 3 領域郭清の適応を見直す必要があ る. 3 領域郭清の適応に関しての報告は多いが, 大半 は組織学的リンパ節転移の有無, 個数, また術後合併 症などから検討した適応である。しかし, 現実には 3 領域郭清を施行するか否かは術前あるいは術中の所見 によって決定しなければならない。 また，3領域郭清 を論じる場合, 頸部に関しては, 頸胸移行部のリンパ 節郭清は胸腔内からもある程度郭清が可能であるの で，実際は鎖骨上リンパ節の郭清をどうするかが問題 となる.一方, 最近の超音波診断の成績は著しく向上 し, 術前に壁樑達度や頸部, 腹部りンパ節転移はもち ろんのこと, 縦隔内リンパ節もかなり正確に診断出来

$<1996$ 年 5 月 8 日受理 $>$ 別刷請求先：福元 俊孝 T 890 鹿児島市桜ケ丘 $8-35-1$ 鹿児島大学医学 部第 1 外科
るようになった。本稿では教室で施行した胸部食道癌 根治手術例の術前診断および治療成績をもとに, 超音 波検查 (以下, US) おょび超音波内視鏡 (以下, EUS) による術前診断に基づく 3 領域郭清の適応，とくに頸 部上縦隔の郭清の適応について検討した.

\section{対象および方法}

1986年から93年に教室で右開胸開腹により cI 以上 の切除がなされた胸部食道癌136例を対象とした。その 内訳は 3 領域郭清105例, 深達度 $\mathrm{mp}$ 以上の 2 領域郭清 31例であった．全例に術前にUS（東芝製 SSA-90A, 3.75 5.0MHz), EUS (東芝製 EPE-7703FL, 7.5 $\mathrm{MHz}$ )を施行した。描出されたりンパ節に対する転移 の有無は, 超音波像における境界エコーおるよ゙内部エ コーの性状より 3 つの型に分類し, 境界が鮮明で内部 エコーの弱いもの（Type 2) と, 境界が鮮明でしばし ば notching を伴い内部に粗大エコーの散在するもの (Type 3) を転移リンパ節とする従来の教室の判定基 準5)に従った（Fig. 1)。 また，郭清されたリンパ節は すべて術中にマップ上に置いて部位を確認し, Hilus を含む最大割面で固定標本を作製し組織学的検討を 行った. 具体的には, 組織学的リンパ節転移の状況, 術前診断の成績, 遠隔成績の検討から術前診断に基づ 
Table 1 Incidence of lymph node metastases of 105 patients with 3-field lymph node dissection

\begin{tabular}{|c|c|c|c|c|c|c|}
\hline \multirow{2}{*}{ Depth of invasion } & \multicolumn{5}{|c|}{ Location of lymph node } & \multirow{2}{*}{ Total } \\
\hline & 104 & 101 & $106-\mathrm{rR}$ & $106-\mathrm{rL}$ & $106 \cdot \mathrm{tL}$ & \\
\hline $\mathrm{ep} \sim \operatorname{mm}(\mathrm{n}=3)$ & - & - & - & - & - & - \\
\hline $\operatorname{sm}(n=18)$ & 11.1 & 5.6 & - & 5.6 & 5.6 & $38.9 \%$ \\
\hline $\mathrm{mp}(\mathrm{n}=16)$ & 25.0 & 31.3 & 18.8 & 31.3 & 6.3 & $75.0 \%$ \\
\hline$a_{1} \sim(n=68)$ & 26.5 & 27.9 & $3 \overline{5} .3$ & 19.1 & 16.2 & $79.4 \%$ \\
\hline
\end{tabular}

104 : Supraclavicular node, 101: Cervical paraesophageal node, 106-rR : right Recurrent nerve node (top of right No. 106), 106-rL: No. 106 nodes along the left recurrent nerve, 106-tL: left tracheobronchial node

Fig. 1 Patterns of ultrasonographic images of lymph node

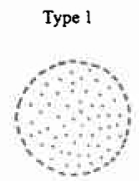

poorly defined



well defined



well defined often with nochings strong
Internal echoes

$$
\text { weak }
$$$$
\begin{aligned}
& \text { weak } \\
& \text { relatively sonolucent }
\end{aligned}
$$

Table 2 Incidence of lymph node metastases in 105 patients with 3-field lymph node dissection according to location of the tumor

\begin{tabular}{l|c|r|r|r|r}
\hline \multirow{2}{*}{$\begin{array}{c}\text { Location of } \\
\text { the tumor }\end{array}$} & \multicolumn{5}{|c}{ Location of lymph node } \\
\cline { 2 - 6 } & 104 & 101 & $106-\mathrm{rR}$ & 106 -rL & 106 -tL \\
\hline $\operatorname{Iu}(\mathrm{n}=10)$ & 30.0 & 40.0 & & 20.0 & \\
$\operatorname{Im}(\mathrm{n}=74)$ & 23.0 & 27.0 & 27.0 & 20.3 & 16.2 \\
$\mathrm{Ei}(\mathrm{n}=21)$ & 19.0 & 4.8 & 23.8 & 14.3 & 4.8 \\
\hline
\end{tabular}

104 : Supraclavicular node, 101 : Cervical paraesophageal node, 106-rR : right recurrent nerve node (top of right No. 106), 106-rL: No. 106 nodes along the left recurrent nerve, 106-tL : left tracheobrochial node

であった. 鎖骨上リンパ節 (No. 104)への転移は sm： $11.1 \%, \mathrm{mp}: 25.0 \%, \mathrm{a}_{1}$ 以上になると $26.5 \%$ に転移が 認められた。 頸部傍食道リンパ節 (No. 101) 転移率は, $\mathrm{sm}: 5.6 \%, \mathrm{mp}: 31.3 \%$, $\mathrm{a}_{1}$ 以上 $: 27.9 \%$ であった。 また106-rR(右反回神経リンパ節，右 106 最上リンパ節 に相当), 106-rL(左106で反回神経浴いのリンパ節), 106-tL（左気管気管支リンパ節，infra-aortic lymph node に相当）など上縦隔リンパ節への転移も $\mathrm{mp}$ で $18.3 \%, 31.3 \%, 6.3 \%, \mathrm{a}_{1}$ 以上で $35.6 \%, 19.1 \%, 16.2 \%$ の症例に転移が認められた（Table 1).

2）占居部位別リンパ節転移の状況

$\mathrm{Ei}$ 症例では上縦隔への転移は106最上で $23.8 \%$ （5/ 21例) に認められ，No. 104は $19.0 \%$ (4/21例) の転移 を認めた。これらの症例はいずれも占居部位が $\operatorname{Im} に$ かかる症例であり，Ei に限局した症例では頸部への転 移は認められなかった. No. 104転移は Im 例で23\%， Iu症例では30\%に転移を認めた（Table 2)。

3）鎖骨上リンパ節転移と反回神経沿いリンパ節転 移との関係

鎖骨上リンパ節転移陽性例のうち，反回神経沿いリ ンパ節に転移を認めた頻度は $75 \%$ (18/24例)であった。 
Table 3 Preoperative and histologic diagnosis of supraclavicular lymph nodes in 105 cases with 3-field lymph node dissection

\begin{tabular}{|c|c|c|c|c|}
\hline \multirow{2}{*}{\multicolumn{2}{|c|}{ Metastasis }} & \multicolumn{2}{|c|}{ Histological diagnosis } & \multirow{2}{*}{ Total } \\
\hline & & Yes & No & \\
\hline \multirow{3}{*}{  } & Yes & 17 & 4 & 21 \\
\hline & No & 7 & 77 & 84 \\
\hline & & 24 & 81 & 105 cases \\
\hline
\end{tabular}

True positive rate: $81.0 \%$, Sensitivity: $70.8 \%$, Accuracy $89.5 \%$

Table 4 Preoperative and histologic diagnosis of recurrent nerve chain nodes* in 105 cases with 3 -field lymph node dissection

\begin{tabular}{|c|c|c|c|c|}
\hline \multirow{2}{*}{\multicolumn{2}{|c|}{ Metastasis }} & \multicolumn{2}{|c|}{ Histological diagnosis } & \multirow{2}{*}{ Total } \\
\hline & & Yes & No & \\
\hline \multirow{3}{*}{ 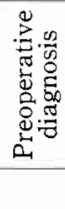 } & Yes & 36 & 13 & 49 \\
\hline & No & 13 & 43 & 56 \\
\hline & & 49 & 56 & 105 cases \\
\hline
\end{tabular}

True positive rate: $73.5 \%$, Sensitivity: $73.5 \%$, Accuracy : $75.2 \%$

* : including No. 101, No. 106-rR and No. 106-rL

逆に反回神経沿いに転移があり，かつ，鎖骨上リンパ 節にも転移のあった症例は $36.7 \%(18 / 49$ 例) であり， 両者には転移経路の上でも密接な関係が認められた。

\section{2. 術前診断成績}

1）鎖骨上リンパ節

術前に転移ありと診断したのは, 3 領域郭清例105例 のうち21例(20.0\%)であった。このうち17例， $81.0 \%$ が組織学的にも転移が認められた。一方，転移なしと 診断した 84 例中 7 例, $8.3 \%$ に組織学的に転移が認めら れた. True positive rate: $81.0 \%$, sensitivity: 70.8\%, specificity：95.1\%であった（Table 3).

2) 反回神経沿いリンパ節

同様に，左右反回神経リンパ節（No. 106-rR， No. 106-rL) と頸部傍食道リンパ節（No. 101）を反回神経 沿いリンパ節と一括して, その術前診断と組織学的診 断について検討した。 その結果, 術前診断にて反回神 経沿いリンパ節に転移ありとした49例中36例，73.5\% に転移があり，一方，転移なしとした56例中13例，
Table 5 The involved area on the section of lymph node in false negative cases

\begin{tabular}{c|c|c}
\hline Involved area & $\begin{array}{c}\text { Supraclavicular } \\
\text { Jymph node }\end{array}$ & $\begin{array}{c}\text { Recurrent nerve } \\
\text { chain node }\end{array}$ \\
\hline$\sim 1 / 3$ & 5 & 3 \\
$1 / 3 \sim 2 / 3$ & 1 & 5 \\
$2 / 3 \sim$ & 1 & 5 \\
\hline Total & 7 cases & 13 cases \\
\hline
\end{tabular}

Fig. 2 Relationship of pre-oprative and pathological diagnosis between supraclavicular lymph node and recurrent nerve chain node

Metastasis



RNC: Recurent nerve chain node, including No.101, 106-rR and 106-rL SCN : Supra clavicular node

$23.2 \%$ に転移が認められた. True positive rate： $73.5 \%$, sensitivity $: 73.5 \%$, specificity $: 76.8 \%$ で あった (Table 4).

3. False negative 症例

術前診断は転移 (-)で, 術後組織診断で転移 $(+)$, すなわち false negative 症例は鎖骨上リンパ節で 7 例 $(8.3 \%)$, 反回神経沿いリンパ節で13例 (23.2\%)であっ た. 鎖骨上リンパ節の 7 例中 5 例が micro metastasis 3 例を含む転移面積が $1 / 3$ 以下の症例であった。また， 反回神経沿いのリンパ節13例では,転移面積が $1 / 3$ 以下 のもの 3 例, $1 / 3 \sim 2 / 3$ もの 5 例, $2 / 3$ 以上のもの 5 例 と, 転移面積が大きいにもかかわらず術前に指摘でき なかった症例もみられた（Table 5).

4. 術前診断からみた反回神経沿いリンパ節と鎖骨 上リンパ節転移の関係

術前診断にて鎖骨上リンパ節の false negative が 84 例中 7 例， $8.3 \%$ あことより，この症例を術前あるい は術中に拾い上げることができないか，反回神経沿い リンパ節との関係から検討した。術前，反回神経沿い リンパ節に転移ありとした49例中15例（30.6\%）に鎖 骨上リンパ節に組織学的に転移を認めた。このうち 13 
Table 6 Details of 5 cases assesed with no metastasis preoperativelly in supraclavicular and recurrent nerve chain nodes, but histopathologically involved at supraclavicular nodes

\begin{tabular}{c|c|c|c|c|c}
\hline Cases & $\begin{array}{c}\text { Location } \\
\text { of tumor }\end{array}$ & $\begin{array}{c}\text { No. of involved } \\
\text { SCN } \dagger\end{array}$ & $\begin{array}{c}\text { No. of involved } \\
\text { RNC }\end{array}$ & $\begin{array}{c}\text { No. of other } \\
\text { involved node }\end{array}$ & $\begin{array}{c}\text { No. of invoved nodes/ } \\
\text { No. of dissected nodes }\end{array}$ \\
\hline 1 & Ei & 1 & $4^{*}$ & 1 & $6 / 97$ \\
2 & Im & 2 & $3^{*}$ & 15 & $20 / 97$ \\
3 & Ei & 2 & $1^{*}$ & 6 & $9 / 77$ \\
4 & Im & 1 & 0 & 0 & $1 / 101$ \\
5 & Im & 1 & 0 & 0 & $1 / 74$ \\
\hline
\end{tabular}

SCN $\uparrow$ : Supraclavicular node. RNC $\ddagger$ : Recuurent nerve chain node, including No. 101, No. 106-rR and No. 106-rL, * : Metastasis was detected at No. 106-rR in operation

Table 7 Clinicopathologic characteristics of 115 patients with thoracic esophageal carcinoma, in whom tumor invaded beyond tunica muscularis propria

\begin{tabular}{l|c|c|c}
\hline & $\begin{array}{c}\text { 3-Field lymph } \\
\text { node dissection } \\
(\mathrm{n}=84)\end{array}$ & $\begin{array}{c}\text { 2-Field lymph } \\
\text { node dissection } \\
(\mathrm{n}=31)\end{array}$ & P.value \\
\hline Male/Female & $82 / 2$ & $30 / 1$ & N.S. \\
Age & $61.6 \pm 7.6$ & $65.6 \pm 8.4$ & N.S. \\
Depth of invasion & 16 & 5 & N.S. \\
mp & 68 & 26 & \\
$\mathrm{a}_{1} \sim$ & 4 & & N.S. \\
stage & 3 & 1 & \\
I & 25 & 2 & \\
II & 52 & 17 & N.S. \\
III & 74 & 11 & N.S. \\
IV & 10 & 27 & \\
Preoperative therapy & & 4 & \\
yes & 49 & 22 & N.S. : not significant \\
no & 35 &
\end{tabular}

例は術前に鎖骨上リンパ節に転移ありと診断されてい たが，2 例は診断されていない false negative 例で あった．術前に反回神経沿いに転移ありと診断した症 例すべてに頸部郭清を施行すると仮定すると，これら 2 例はその対象となる．その際問題となるのは，反回 神経沿いに転移なしと診断した症例における鎖骨上リ ンパ節転移の存在である。その頻度は56例中 9 例 (16.1\%)であった.このうち 4 例は術前に鎖骨上リン パ節転移陽性と診断されていたが， 5 例は診断されて いない false negative 例であった (Fig. 2).しかし， この 5 例のうち 3 例は,術中に右 106 最上リンパ節に転 移が肉眼的に確認できた症例であった。すなわち，術
前または術中に反回神経沿いに転移ありと診断した症 例も鎖骨上リンパ節郭清の適応とするならば，false negative 7 例中 5 例は郭清群に入り，2例 (2.4\%) の みが頸部郭清の対象外となってしまう。この 2 例は, 郭清個数がそれぞれ74個, 101個中わずかに 1 個のみの 転移で，しかもそれが鎖骨上リンパ節という例外的と もいえる症例であった (Table 6). 組織学的にもリン パ節のごく一部にのみ癌細胞を認め, 術前, 術中の診 断では転移の指摘は困難と思われた。

\section{5. 遠隔成績}

All over で遠隔成績を検討すると， 2 領域郭清例の 方が 3 領域郭清例より良好であるが，これは 2 領域郭 
Fig. 3 Acutuarial survival curves of patients with esophageal carcinoma which invaded beyond the proper muscle

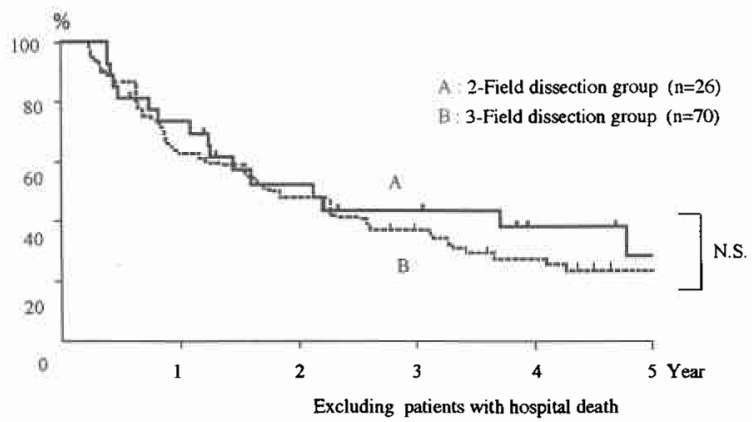

Fig. 4 Acutuarial survival curves of patients assessed with no metastasis preoperativelly at supraclavicular and recurrent nerve chain nodes, and in whom the tumor invaded histopathologically beyond the proper muscle

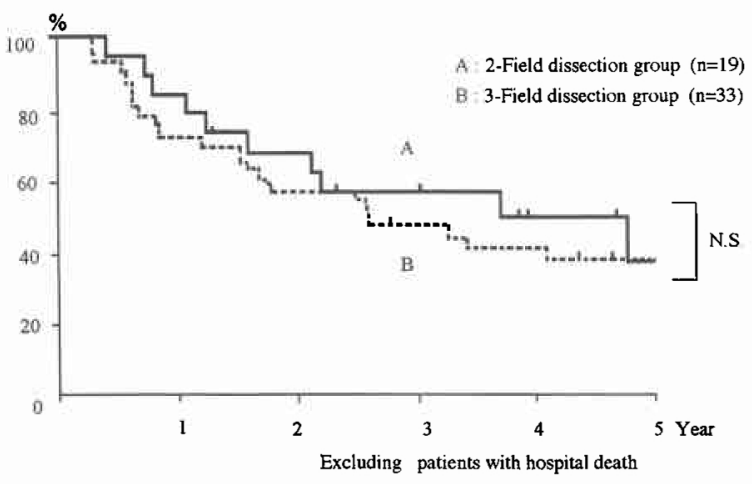

清例に早期癌が多いためである。そこで背景因子を揃 えるために $\mathrm{mp}$ 以上の症例で検討した，背景因子に差 は認めなかった (Table 7). 5 生率は 2 領域郭清例で $28.8 \% ， 3$ 領域郭清例で $24.5 \%$ 差はみられなかった (Fig. 3).さらに術前鎖骨上および反回神経周囲リン パ節に転移 negative と診断した症例においては，2領 域郭清例で $37.2 \% ， 3$ 領域郭清例 $37.7 \%$ と両群に差を 認めなかった (Fig. 4).すなわち, 術前に鎖骨上リン パ節および反回神経沿いリンパ節に転移陰性と診断す れば，2領域郭清でも頸胸移行部から上繸隔の左右を 十分に郭清することにより 3 領域郭清と同じ遠隔成績 が得られるものと思われる。一方, 鎖骨上リンパ節ま たは反回神経沿いリンパ節に転移陽性と診断した症例 は, 全例 3 領域郭清がなされていたため，2 領域郭清 と 3 領域郭清別の生存率を比較することはできなかっ
た.

\section{考察}

胸部食道癌に対するリンパ節郭清の術式も時代とと もに大きな変遷がみられる，当教室においても従来の 2 領域郭清では頸部は勿論, 上緹隔でも左側は全く郭 清していなかった時代を経て，1983年からは左右の上 綐隔を含む 3 領域郭清を積極的に行ってきた，その結 果, 気管の左側にも右側とほほ同率でリンパ節転移が 認められたことから，最近では 2 領域郭清でも早期癌 を除いては気管の左右は原則として郭清している.胸 腔内からの郭清により頸部傍食道リンパ節も甲状腺の 下極付近までは郭清できることより，3 領域郭清と 2 領域郭清の相違は鎖骨上リンパ節の郭清を施行するか 否かの差違といっても過言ではない. 少しでも 3 領域 郭清による侵襲を少なくするためには，鎖骨上リンパ 節郭清の必要な症例を如何に術前に診断するかが重要 となる。

腫場の深達度とリンパ節転移には密接な関係が認め られるが,一般的には ep $\mathrm{mm}_{2}$ までの癌には転移がな いとされている。遠藤ら”は，本邦の食道粘膜癌 500 例 の検討で, ep 癌にリンパ節転移はなく, $\mathrm{mm}$ 癌の $7 \%$ に転移を認めたと報告している，教室の表在癌の検 討8)でも, $\mathrm{mm}_{2}$ までの癌ではリンパ節転移は認めない ことより，これらの症例は頸部郭清はもちろん必要な く,内視鏡的粘膜切除術や非開胸食道抜去術など縮小 手術の適応と考えられる．また，癌占居部位に従いリ ンパ節転移には一定の解剖学的な傾向がある ${ }^{9) \sim 11} に$ せよ, $\mathrm{Ei}$ 症例でも転移は 3 領域におよぶ可能性は否定 できない.しかし，今回の検討において，Ei 例で鎖骨 上に転移を認めたのは主たる占居部位が $\mathrm{Ei} て ゙ 一$ 部 $\mathrm{Im}$ にかかる症例であったことより, Ei より肛閏側に明ら かに限局している症例では術前に転移が指摘されない 限り 頸部郭清は不要であり, 上綎隔の郭清も省略して もよい症例も存在すると思われる。

術前のリンパ節の転移診断に関しては, 頸部吅よび 頸胸移行部は体外エコーで, 縦隔は EUS での検索が 必要となるが, EUS では鏡体が病変部を通過するかど うかが問題となる．今回の検討でも $30.2 \%$ の症例が狭 窄のために病変部を越えられず壁梁達度の検索ができ なかった。しかし，上縦隔のリンパ節転移の検索は Iu 症例10例中，鏡体不通過による検索不十分なものは 1 例のみであった。

リンパ節転移の術前診断率は，鎖骨上リンパ節で true positive rate: $81.0 \%$, sensitivity $: 70.8 \%$, 
accuracy： $87.5 \%$, 反回神経沿いリンパ節ではやや低 く，おのおの $73.5 \% ， 73.5 \% ， 75.2 \%$ であた。宇田 川ら ${ }^{12)}$, 日月ら ${ }^{13)}$, も我々と同様の成績を報告してお り, 教室の診断成績も妥当であると考えられる. False negative 症例での誤診の理由として，1）上縦隔の気 管周囲, とくに右から前面に位置するリンパ節が超音 波内視鏡の死角になりやすいこと，2）径が $5 \mathrm{~mm}$ 以下 のものや,割面に占める転移面積が $1 / 3$ 以下の転移など が主であった。いずれにしろ，鎖骨上リンパ節にして も, 超音波診断が $100 \%$ 正確でない以上, 見逃された症 例をいかにして 3 領域郭清の対象例とするかが問題と なる.今回の検討では 7 例 (8.3\%) が false negative であった.そこで本研究では false negative 症例を反 回神経沿いリンパ節転移診断状況から拾い上げられな いか否かを検討した。なぜならば鎖骨上リンパ節と反 回神経沿いリンパ節のとは転移経路や転移率の面でも 密接な関係にあるからである。また, 術前反回神経沿 いリンパ節に転移ありとした症例の $30.6 \%$ に鎖骨上リ ンパ節に組織学的転移を認めることも考慮して, 術前 あるいは術中に反回神経沿いリンパ節に転移がある症 例も鎖骨上のリンパ節郭清の適応であると考えた。そ の結果，今回の対象136例中では 2 例，1.5\%のみが鎖 骨上リンパ節に転移がありながら頸部郭清の対象外と なる。これらの症例はリンパ節転移が 1 個で, かつ鎖 骨上リンパ節のみの転移という例外的な症例であり， 術後 follow up 中に転移と診断した段階で郭清を施行 することでも対処できると考えられる，なお，このよ うな方針で術前および術中に反回神経沿いに転移あり とした症例すべてに鎖骨上リンパ節郭清を施行する と, 52例 (術前診断49例+術中 3 例) のうち 34 例 (65.4\%) は結果的 over surgery となってしまうがリ ンパ節転移に関する診断能の現況と根治性を考慮する と許容されるものと考えられる。

遠隔成績について，3 領域郭清例が有意に予後良好 であるという報告は多( ${ }^{10) 14) 15}$. Isono ら ${ }^{16)}$ は, 全国96 施設の 4,590 例の食道癌の成績を集計し, その結果, 3 領域郭清例の 5 生率は $34.3 \%$ で 2 領域郭清例の $26.7 \%$ に比べて有意に（ $\mathrm{p}<0.001 ）$ 良好と報告している.一 方, 安藤ら ${ }^{17)}$ は over all では両群間に有意の差はなく, stage 0, I, II 症例とくに n (-) 例で 3 領域郭清が 有意に有効であったとしている。磯野ら ${ }^{18)}$ は逆に n (一) より $\mathrm{n}(+)$ 症例に効果あるとしている。このよ うに遠隔成績に関寸る評価は報告者によって異なって いる. その理由として, 各施設とも historical control
との比較であるため, とくに 2 領域郭清例は教室でも そうであったように，上縦隔の郭清が現在のように気 管の両側や頸胸移行部など徹底していないなど，背景 因子のバラツキが多いことなどが推測される．掛川 $ら^{19)}$, 渡辺ら ${ }^{20)}$ も, 上縦隔リンパ節郭清を十分に施行す れば，頸部リンパ節郭清の有無では予後に差を認めな いと報告している. 今回の著者らの検討でも, 背景因 子を揃えるために $\mathrm{mp}$ 以上の症例で検討すると, 術 前・術中に転移なしとした症例での 5 生率は， 3 領域 郭清例 $37.7 \% ， 2$ 領域郭清例 $37.2 \%$ と両群間に差を認 めなかった。すなわち，術前・術中に転移なしと診断 すれば，頸胸移行部を含めた上縦隔の左右を郭清する 2 領域郭清でも 3 領域郭清と変わらない成績を得るこ とが可能である。もちろん，術前頸部リンパ節および 上縦隔転移例における 3 領域リンパ節郭清の意義を否 定するものではない.

以上の結果から, 胸部食道癌に対する頸部郭清は術 前超音波診断ならびに術中所見により鎖骨上リンパ節 または反回神経沿いリンパ節に転移がなければ省略で きるものと思われる。

な扔, 本要旨は第 45 回日本消化器学会総会 (横浜市)にて 発表した。

\section{文 献}

1）馬場政道, 草野 力, 福元俊孝注加：食道癌術後合 併症の検討 -3 領域郭清例と 2 領域郭清例の比較 一. 日消外会誌 $22 ： 1970-1976,1989$

2) 夏越祥次, 島津久明, 吉中平次ほか：食道癌 3 領域 リンパ節郭清後の再発と対策. 手術 $45: 1743-$ 1748, 1991

3) Baba M, Aikou T, Yoshinaka $\mathrm{H}$ et al: Longterm results of subtotal esophagectomy with three-field lymphadenectomy for carcinoma of the thoracic esophagus. Ann Surg 219:310316, 1994

4）福元俊孝, 徳田和信, 浅谷倫代任：高齢者食道癌 手術における 3 領域郭清の評価と問題点. 日消外 会誌 28：979-986, 1995

5) Yoshinaka H, Nishi M, Kajisa $T$ et al: Ultrasonic detection of lymph node metastases in the region around the celiac axis in esophageal cancer. J Clin Ultrasound 13:153-160, 1985

6）食道疾患研究会編：食道癌取扱い規約. 第 8 版. 金 原出版, 東京, 1992

7）遠藤光夫, 河野辰彦：食道粘膜内癌の臨床的検討 一本邦集計切除術500例の分析一. 外科治療 66 : 248-251, 1992

8）吉中平次, 島津久明, 夏越祥次ほか：早期食道癌の 外科的治療. 臨床内科 7:1745-1754, 1992 
9) Nishihira $T$, Sayama J, Ueda $\mathrm{H}$ et al: Lymph flow and lymph node metastasis in esophageal cancer. Surg Today 25:307-317, 1995

10) Akiyama $H$, Tsurumaru $M$, Udagawa $H$ et al: Systemic lymph node dissection for esophageal cancer-effective or not? Dis Esophagus 7:213, 1994

11）吉中平次, 島津久明, 森永敏行ほか: 胸部食道癌の リンパ節転移状況と術前超音波診断成績 -3 領域 郭清例における検討一. 日消外会誌 $24 ： 2881-$ 2887, 1991

12）宇田川晴司, 鶴丸昌彦, 渡辺五朗ほ加：超音波検查 亿よる食道癌顓部・上綎隔リンパ節転移診断能の 検討。日消外会誌 $19: 2176-2183 ， 1986$

13）日月祐司, 加藤抱一, 渡辺 寛ほか：食道癌の術前 内視鏡超音波検查と莖部超音波検査の有用性. 日 消外会誌 $24 ： 956-961 ， 1991$

14）平山 克, 森 昌造：胸部食道癌に対する頸部上 縦隔拡大リンパ節郭清. 消外 $14: 1769-1780$,
1991

15) Kato $\mathrm{H}$, Watanabe $\mathrm{H}$, Tachimori $\mathrm{Y}$ et al: Evaluation of neck lymph node dissection for thoracic esophageal carcinoma. Ann Thorac Surg 51:931-935, 1991

16) Isono $K$, Sato $H$, Nakayama $K$ : Results of a nationwide study on the three-field lymph node dissection of esophageal cancer. Oncology 48 : $411-420,1991$

17）安藤暢敏, 篠沢洋太郎, 菊永裕行ほか：胸部食道癌 に対する 3 領域郭清の評価. 日外会誌 $90: 1616$ $-1618,1989$

18）磯野可一，奥山和明：胸部食道癌に対する 3 領域 リンパ節郭清の評価。消外 $12: 163-170,1989$

19）掛川暉夫, 山名秀明：胸部食道癌の外科治療の進 歩.癌と化療 $22 ： 855-862 ， 1995$

20）渡辺 寛, 加藤抱一, 日月祐司：胸部食道癌根治術 に抢ける縮小手術，とくにリンパ節郭清の縮小化 の可能性. 日臨外医会誌 56:901-902，1995

\title{
Indication of Cervical Lymph Node Dissection for Thoracic Esophageal Carcinoma According to Preoperative Diagnosis with Ultrasonic Examination
}

\author{
Toshitaka Fukumoto, Heiji Yoshinaka, Toshiyuki Morinaga, Shouji Natsugoe, \\ Kazunobu Tokuda, Mario Shimada, Kazusada Shirao, Chikara Kusano, \\ Masamichi Baba and Takashi Aikou \\ First Department of Surgery, Faculty of Medicine, Kagoshima University
}

In this series, the indication for cervical lymph node dissection for thoracic esophageal carcinoma was investigated by preoperative ultrasonic examination of nodal metastasis at supraclavicular and recurrent nerve chain nodes. During the period from January 1986 to December 1993, a total of 136 patients with thoracic esophageal carcinoma were curatively operated on by right thoracotomy and laparotomy. Of these, 105 patients underwent 3-field lymph node dissection and 31 underwent 2-field dissection. 1) Lymph node metastasis was detected histopathologically in 7 of 84 patients who were assessed preoperatively as having no metastasis of the supraclavicular node. 2) Five of these 7 false negative patients were also assessed preoperatively or during operation as having metastasis of the recurrent nerve chain nodes. 3 ) And so, it is risky to determine the cervical lymph node dissection only by assessment of supraclavicular lymph node. However, in $97 \%$ of patients ( $82 / 84$ cases), it is possible to determine the indication of cervical lymph adenectomy, adding to assessment of recurrent nerve chain node. 4) For patients in whom the tumor invaded beyond the proper muscularis, the 5 -year survival rates were $37 \%$ in cervical lymph node dissection group, similar to those of no dissection group. 5) The indication of cervical lymphadenectomy is for such patients assessed preoperatively as having metastasis of the supraclavicular or recurrent nerve chain node.

Reprint requests: Toshitaka Fukumoto First Department of Surgery, Faculty of Medicine, Kagoshima University 8-35-1 Sakuragaoka, Kagoshima, 890 JAPAN 